\title{
TEXTING LITERACIES AS SOCIAL PRACTICES AMONG OLDER WOMEN
}

\author{
Charlyn Dyers
}

University of the Western Cape

While many studies on mobile messaging have tended to focus on the communicative practices of the urban young, this paper considers the role of mobile messaging (also called texting) both as a social practice as well as a form of literacy enhancement among a group of older working class women between the ages of 50 and 80 in a Cape Town township. The paper examines how these women, with little or no formal education, acquire this form of literacy, as well as the purposes for which they use texting. It also explores how this form of late-modern communication is adding to four of their existing or developing literacies - text, numeracy, visual and personal. The paper therefore adopts a multiliteracies approach within the context of portable literacies.

\section{Keywords}

texting, multiliteracies, older women, social practices, voice, citizenship, Cape Town, township

\section{INTRODUCTION}

This paper presents an examination of mobile messaging or texting as a social practice and a particular form of literacy acquisition among one group of older women in a Cape Town township. It forms part of a larger study (Slemming, 2011; Dyers \& Slemming, 2014 in press; Williams, 2012; Dyers, Williams \& Barthus, 2012) that examines the portability of multiliteracy resources. These resources include people's existing multiliteracies; imported aspects of the linguistic landscape of an area using signs produced elsewhere; and mobile literacies (acquired through mobile messaging/texting). Our understanding of multiliteracies is informed by Mills (2011:96) who stresses the plurality of literacy resulting from 'multiple, competing discourses and identities in multicultural societies'. Dyers and Slemming (2014 in press) more specifically see portable multiliteracies as literacies acquired either formally or informally by individuals which have been transferred to new shared (urban) spaces as a result of translocal or transnational migration. Through collective sharing and activation, these multiliteracies are passed on to others, giving them particular strategies for negotiating these new spaces.

Our research and those of others (e.g. Thurlow, 2003; Blommaert \& Velghe, 2013) have shown that, for older women, much of their informal acquisition of literacy takes place through normal daily socialising in real and virtual space with peers as well as younger people. The use of mobile telephones appears to have played a significant role in such literacy acquisition, especially as most people in South Africa either own, or at least have access to, at least one mobile telephone (called cell phones in South Africa). Blommaert and Velghe 
(2012:6) comment that even 'people with modest means manage to take part in the new communication environment'. This was confirmed by a recent three-country study by Porter (2011) that showed that mobile or cell phone ownership is high even in low-income areas. Even in remote rural areas, according to this study, up to $43 \%$ of people own cell phones, and this figure rises to $67.5 \%$ in urban areas.

Obviously, the ability to send text messages requires more than just owning or having access to a cell phone. Blommaert and Velghe (2012:6) found that 'device illiteracy' was very high among the middle-aged women in their study in Wesbank, a township with some similarities to the one where this study was conducted. Deumert and Lexander (2013:525) note that, for effective texting,

...one also needs to be able to write messages (using a keypad) and to read messages (on a fairly small screen). It is a type of literacy, and thus a semiotic practice, which is not separate, but certainly different, from school-taught literacies.

This paper provides more evidence of how older women in particular acquire this type of literacy and also looks at the kind of messages they are able to write and read, with or without assistance from others.

\section{BACKGROUND}

Like the rest of the developing world, South Africa is experiencing very intense translocal migration from the rural areas to the cities as well as ongoing transnational migration, particularly from other African states. In new shared urban spaces like the township in our study, people now live in areas characterised by a diversity of languages and cultures, and very often the educational resources provided by the state cannot meet the needs of everyone in the community. Women in these new spaces are often the ones most marginalised in terms of opportunities to improve their existing skills and literacy. Rockhill (1993:164-5) also argues that literacy is socially constructed in the practices of everyday interaction and the gendered nature of literacy comes sharply to the fore where women speak little English and when access to quality schooling is highly problematic.

The data for this small-scale study was collected in Netreg, a section of Bonteheuwel, one of the largest townships in Cape Town. It is quite close to the centre of the city, and enjoys good road and rail connections. While many of its inhabitants find employment in other parts of the city, Netreg is known for a single micro-economy, scrap collection, which is undertaken by young men driving horse-carts (Torkelson, 2009). This is a strong, close-knit community that has bonded together to assert their rights for proper housing (Torkelson, 2009). The housing in the township was co-financed by the Nial Mellon Townships Initiative, an Irish-funded charity, and the development has a much better quality of houses than the state-provided housing of other townships. The community is a blend of original Bonteheuwel residents and translocal migrants from other parts of the Western Cape Province and South Africa.

The eight women in this study were friends who had moved to Netreg from different parts of Cape Town or from different towns or provinces. They predominantly were speakers of Afrikaans, but most knew some English, and those who had moved to Cape Town came in search of work and to be with family members. Once contact had been established with the 
group through a key informant whose house was a regular meeting place for this group of friends, the permission of the group was sought to interview and observe them. In addition they were asked to send a selection their (self-censored) mobile messages to the researcher's cell phone. Small payments were made to each of the eight women in order to cover the costs of sending and forwarding their mobile messages. Informed consent, which included ensuring their anonymity and the non-disclosure of sensitive information, was obtained to use the data.

\section{THEORETICAL AND CONCEPTUAL FRAMEWORK}

The theoretical starting point for this paper was the sociolinguistics of mobility (Blommaert, 2010) which acknowledges the fact that the late-modern world is characterised by globalisation and a greater mobility of people - in both physical and virtual space - than at any time. 'Mobility is something that has spatial as well as temporal features and mobile text is text that has the capacity to travel through time and space' (Blommaert, 2010: 24). In South Africa, more than $60 \%$ of all people now live in cities, and these cities are struggling to cope with the massive demand for housing and other major services. Many of the new migrants have to make do with living in make-shift informal settlements or squatter camps. The migrants are either translocal, like the women in the study, or transnational, coming from a range of countries, but especially from other African countries like Zimbabwe, the Congo, Nigeria and Somalia. Cape Town is becoming increasingly diverse in terms of its population as well as the linguistic resources people bring with them from other places.

The study also draws on the work of the New Literacy Scholars (Gee, 1990; Street, 1995; 2003), who contend that literacy is a socially constructed practice and not something 'out there'. These scholars recognise the existence of multiple literacies that vary and are contested according to time and space and in relations of power. For Mills (2011: 96), a multiliteracies approach 'acknowledges the multiple ways of communicating for different cultural and institutional purposes'. In his Introduction to a special issue on Ethnographies of Literacy, Baynham (2004) refers to three generations of literacy studies - the earlier work, which focuses on the orientations to literacy pedagogy; the second generation which falls in a period highlighting the importance of multimodality; and the 'third generation', which looks at ethnographic studies of 'out-of-school' literacies by, e.g. Masny (2005) and Gregory, Long and Volk (2005). In a recent 'third generation' study done in rural Botswana, Macheng (2011: 20) draws the interesting conclusion that people without schooling 'can mobilize local forms of knowledge and resources and thereby accomplish the literacy-linked tasks that are part of their lives'.

The study on which this paper is based clearly belongs to the 'third generation' of literacy studies as the learning that was done by the research participants took place as a result of the informal assistance of their peers and younger relatives who already possessed some proficiency in texting. The greater competence of younger people in texting and the transfer of such skills to older people is one of the core differences between texting and other literacy practices. Lexander (2011: 14) notes that texting is relatively independent from 'formal social institutions' and that it reverses the 'power relations at the core in other literacy practices', where, traditionally, the young are taught by older people. The type of intergenerational learning that took place among the women and their younger relatives in this study is similar to that described by Kenner, Ruby, Jessel, Gregory and Arju (2007), who looked at intergenerational learning between children and grandparents in east London. Among the 
Netreg women, the same degree of 'intergenerational interdependence' and 'co-construction of learning', as reported by Kenner et al. (2007:221) took place between the women and especially their grandchildren. While these women were caregivers and teachers of more traditional aspects like good behaviour to their grandchildren, the latter, with their far greater competence in new technologies like cell phones, were able to transfer this knowledge to their grandmothers.

Texting undoubtedly has great potential for the acquisition of new literacies as well as the enhancement of existing literacies. Unsworth (2008:3) argues that it should be acknowledged that information communication technologies (ICTs) are affecting the very nature of literacy texts themselves, not only making communication possible in new ways, but also making it possible to make new kinds of meanings:

...there seems to be broad agreement that literacy can no longer be thought of as involving language alone and that images, in paper media texts, and also sound movement and gesture in digital multimedia texts, need to be considered along with language as fundamental meaning-making resources in constructing texts.

In addition, Thurlow and Poff (2009) note that the defining feature of texting is the sociable function of such messages, particularly in their discursive content and communicative intent, adhering more to conversational norms rather than a more prescriptive form of written communication. This sociable function implies that texting is a resemiotisation of spoken discourse - an adaptation from the oral code to the written one. Iedema (2003:48) defines resemiotisation as '...how meaning makes shifts from context to context, from practice to practice, or from one stage of a practice to the next'. Texting, as a new form of meaningmaking, is clearly 'less restricted when it comes to orthography and language choice' (Lexander, 2011: 14) and therefore gives texters much greater freedom in sending messages with whatever linguistic and multimodal resources they have at their disposal without the restrictions of 'correctness'.

Resemiotisation in texting is particularly apparent in the different shortening strategies that have to be learned by texters in order to be able to send short yet comprehensible messages owing to the limited character space (about 160 characters) on the screens of mobile phones (Crystal, 2001: 229). In addition, for people with low incomes like the women in this study, shorter messages are cheaper. 'Non-standard spellings are a central resource texters use to perform - and even to dramatize - informality and to project a persona who is well versed in the rules of, and the expectations surrounding, digital writing' (Deumert \& Lexander, 2013:531). In this regard, Bieswanger (2007: 4-5) identified the following categories of shortenings:

- Initialisms - shortenings that consist of the first letter (or letters) of a combination of more than one word, which is then pronounced as one word. An example here would be LOL (for 'laugh out loud');

- Clippings - here parts of a word are deleted, for example 'b' (for 'be') or 'bday' (for 'birthday');

- Contractions - combinations of two words, very similar to clippings, for example 'wana' (for 'want to');

- Letter-/Number homophones (also called Rhebus writing) - letters or numbers which are pronounced like particular words are used to replace part of all of a word, for example '18' for 'late'; 'c u' for 'see you'; 
- Phonetic Spellings - these include all forms that are shorter than the original words they represent, e.g. 'gudnyt' for 'good night'; and finally

- Word-Value Characters - characters representing words, e.g. 'xoxo' for 'hugs and kisses' or 'mwah' to represent the sound of a kiss.

There of course are reasons beyond the merely sociable for sending a text message. Texting may be 'relatively independent from formal social institutions' (yet) 'is nevertheless embedded in broader social goals and cultural practices' (Lexander, 2011: 14). In addition, Thurlow (2003) provides the following orientations as the main reasons why people send mobile messages: (1) the Informational-Practical Orientation; (2) the InformationalRelational Orientation; (3) the Practical Arrangement Orientation; (4) the Social Arrangement Orientation; (5) the Salutory Orientation; (6) the Friendship Maintenance Orientation; (7) the Romantic Orientation; (8) the Sexual Orientation; and (9) Chain Messages. Text messages are therefore clearly communicative, context-specific events. Among older women, like the ones in this study, texting serves very specific functions. Kurniawan, Mahmud and Nugroho (2006: 990) note that people over the age of 60 use mobile phones for very limited purposes, such as for calling or texting in emergency situations. Melenhorst, Rogers and Caylor (2001) agree that the main benefits of mobile phones for older persons are to keep in touch with someone emotionally close. Thurlow (2003) further stresses that the majority of text messages sent by older women seem to fulfil a social-relational or phatic function, as opposed to informational or practical purposes.

It can also be argued that finding a way into the world of text via mobile messaging within an informal supportive environment is a vital component in helping these women to exercise their rights as participatory citizens who use texting as a means of finding, and expressing, their own voice. Giroux (1988: 199) argues that voice, in the context of a critical theory of education, is an indication of how individuals affirm their own class, cultural, racial and gender identities. For Deumert and Lexander (2013:526) 'texting as a genre is characterized by linguistic form as well as social action'. Participatory citizenship, in the context of a new democracy like South Africa, relates in particular to the societal structures (of family, community, local government, et cetera) that people need to negotiate actively in order to become active citizens (Stroud, 2009; Sutton, 2008) if one takes into account Schinkel's (2008:10) definition of citizenship as 'the modern, democratic form of political membership'. For people with incomplete education, exercising such membership and negotiating essential societal structures can be very problematic. Like the women in this study, they are often the most marginalised in society and are relegated to second-class positions instead of being seen as first-class, active citizens. Texting may therefore be one of the means through which these women can begin to express their own voice as part of exercising their citizenship.

\section{METHODOLOGY}

The methodology used for this study was largely qualitative in nature. The starting point for the research was to work with a key informant the researcher had known for many years, whose own entry into the world of texting had been observed from the first time this informant had acquired a cell phone, which was roughly at the same time that the researcher first bought one. Each had her own struggles in getting to grips with this new medium of communication, and often laughed about their shared battles with the new technology irrespective of their different levels of education. It was through this key informant, Philda (real name used with her permission), that the researcher was introduced to her group of 
friends in Netreg township, where she lived. Once contact had been established with Philda's group of friends, the data for this study was collected through interviews and observations. This was followed by obtaining the women's permission for them to forward messages of their choice to my cell phone for further analysis.

\section{Research participants}

With the exception of the name of the key informant, no real names have been used here. Apart from Philda, Ria and Anna, none of the women had gone to school. The short biographies provide the names of the towns they migrated from to Cape Town as well as some information on their current engagement with mobile literacy.

Key informant Philda (56 years of age): Formerly from Sedgefield in the Southern Cape, Philda came to Cape Town in search of domestic work in 1993. She had completed primary school, but had been forced to drop out of secondary school in Grade 8 owing to her family's poverty. Nevertheless, the degree of literacy she already possessed made it easier for her to learn how to send mobile messages with the aid of her children, especially her eldest son. Philda, like certain younger family members of the other women, functioned as a literacy mediator and general advisor among her group of friends. Hernandez-Zamora (2010: 70) refers to literacy mediators as '...more expert practitioners...' or '....intellectual sponsors'. It will be seen from the various interview responses that Philda was active in helping some of the members of her group in acquiring cell phone literacy, which further developed her own skills in texting through this type of collaborative learning.

Lolla (65): Originally from the rural town of Grabouw, Lolla gave an extensive account of how her 15-year-old grandson helped her to use his cell phone, a very cheap Motorola. He would spend hours sitting next to her, taking her hand and patiently showing her step by step what to do. Lolla never attended school, but is clearly keen to learn through this medium.

Adri (75 years of age): Formerly from the rural town of Paarl, she was taught to use the cell phone by her 40-year-old daughter. She sends her messages with the assistance of her daughter, but is very excited about the prospect of eventually doing this on her own.

Malie (72): Originally from the rural town of Worcester, she was taught to use the cell phone by her 16-year-old grandson. At this stage, she relies on the grandson to help her type her messages.

Ria (59), who had moved to Netreg from another Cape Town township (Hanover Park), was also taught to use the cell phone by the grandchild she was helping to raise and with whom she spends hours just playing on her daughter's cell phone. Ria had two years of primary school before dropping out of school to help her mother at home.

Linda (a youthful 80-year-old), from the Karoo town of Graaff Reinet, is being taught by her daughter, who types her messages.

Anna (43), who moved from a Cape Town squatter camp to Netreg, has no cell phone of her own, but is learning on Philda's phone as a result of their being next-door neighbours. The two of them also play games together. According to her, she attended primary school for three years before dropping out to find work. 
Willemina (50), originally from Beaufort West and with no experience of formal schooling, lived a fairly lonely life as her daughter was at work during the day and had no children. Meeting Philda transformed her life, and she now practises her texting with the group of friends and on her own.

Apart from the obvious poverty and educational deprivation these women faced in their lives, these biographies reveal the importance of the social dimension in the learning of these women, and their willingness to be helped by their peers and younger family members. What also emerges is that this type of literacy is portable, in that it can be transferred from literacy mediators to others through collective sharing and activation.

\section{Data and data analysis}

\section{Interview Data}

One lengthy interview was conducted with Philda as key informant, which was recorded, transcribed and translated. This was followed by short individual interviews with the other women on the two occasions that the researcher was able to meet with, and observe them. To put them at their ease, the researcher did not use a voice recorder but kept careful notes of what they said, and exactly how they said it. Thematic content analysis was applied to the interview data. For Stemler (2001), content analysis is a systematic, replicable technique for compressing many words of text into fewer content categories based on explicit rules of coding, and particularly useful for discovering and describing the focus of individual, group, institutional, or social attention. The coding of the interview data relied on those points that repeatedly emerged in both the longer interview as well as the shorter ones.

\section{Observations}

As noted above, the researcher was invited to Philda's house on two occasions to meet with the group. She observed closely how they played games on their cell phones and showed off their skills in texting to one another. In order to make the experience as relaxed as possible, some refreshments were served and the researcher spoke to them in the informal, colloquial Afrikaans best known to the women. Notes were taken of these observations, and used to support other evidence of literacy development emerging from the interviews and text messages provided.

\section{Text Messages Provided}

A total of 18 sent and received messages were sent to the researcher's cell phone by the participants. The number and the length of the messages received from each woman varied depending on their individual skill in texting and what they were willing to send. Most of them managed to send two messages, with the exception of Linda and Malie, who sent one message each.

Both content and linguistic analysis was applied to the available text messages. Content analysis of these messages grouped them into three different categories. The resulting categories provided more evidence that older women are particularly focused on the socialrelational or phatic function of texting (Thurlow, 2003). The focus of the linguistic analysis was on word choice; the ability to convey short but effective messages bearing the cost of 
individual characters in mind; the presence of particular languages/codes; code switching; and the use of key features of texting following Bieswanger's (2007) classification.

\section{FINDINGS}

\section{The Interviews}

The interview data was transcribed or captured exactly as the women spoke. The first theme that emerged from the interview data was the women's enthusiasm for learning via this new technology. This can be seen in the following extract from the interview with Lolla:

'Dit is ' $n$ voorreg om te kan leer skrywe want my ouers kon dit nie deford om my skool toe te stuur nie. Jy leer gou op selfouns, is makliker om te skrywe, selfouns is voordelig. Jy kan iemand bel wat siek is, boodskappies stuur.' (It's a privilege to be able to write, because my parents could not afford to send me to school. You learn quickly on cell phones, it's easier to write, cell phones are advantageous. You can call someone who is ill, send messages.)

As they were keen to acquire a particular form of literacy like texting, their enthusiasm would obviously have had a positive impact on their learning. It appears that this kind of learning is both more enjoyable and easier than conventional ways of gathering semiotic resources needed to help them find their voices through this medium. For Willemina, an additional advantage is that her cell phone helps her to pass the time during the day and eases her loneliness. She loves playing games on the cell phone, and can sit for hours engrossed in games like 'slangetjies, blokkies, karretjies' (snakes, blocks, cars) while waiting for her daughter to come home from work.

The second major theme that came through very strongly in the interviews was their reliance on younger family members as literacy mediators to initiate them into this new form of technological literacy. Most of the women in this study looked after their grandchildren during the day and part of their interactions included playing with the family cell phone. They reported learning a lot about cell phones and the sending of messages because of this type of intergenerational interaction and subsequent transfer of knowledge from their grandchildren to them. Philda provided the following information:

'Toesie selfouns inkom het ek dit nie eintlik reg verstaan nie. En toe het my kinders my geleer. Toe hulle my begint leer het ek altyd sterretjies gemaak waar ek moet stop ... Ek roep hulle nou nog om my reg te help noudat my foun innie water geval het. M het hom mooi drooggemaak, simkaart ook drooggemaak. En die babatjie $\hat{o}$, $R$ ôk, wys my om die kêmera te gebruik'. (When cell phones came in, I did not really understand it. And then my children taught me. When they began to teach me I always made asterisks when I came to the end of sentences...I still call them to help me (especially) now that my phone has fallen into the water. $\mathrm{M}$ dried it nicely, also the simcard. And the baby also, $\mathrm{R}$ also, shows me how to use the camera.)

Thus her sons were not only effective teachers, but were also very helpful with other more technical problems regarding her cell phone.

Lolla had nothing but praise for her grandson and the hours he spent teaching. According to her, he would say: 
'Kom ouma, ouma moet nou so druk, dan moet ouma weer druk, en as ouma space wil hê dan druk ouma onner. En as ouma wil by 'a' kom dan druk ouma hier.' (Come granny, granny must press like this, then granny must press again, and when granny wants space, granny must press underneath. And if granny wants to get to the letter ' $a$ ' then granny must press here.)

The patience of these young people in taking on the role of teachers to their older relatives reveals their pride in their more powerful positions as masters of this new technology. In a project proposal entitled 'Adult literacy through mobile phone texting', Blommaert (2010) contends that knowledge of how to use cell phones is a new form of social and cultural capital which young people have, and many older people lack. In addition, young people are highly competent users of the shortening techniques outlined by Bieswanger (2007), and older people (as was confirmed by this study) eventually learn these techniques from their younger family members as well as their peers.

The third theme to emerge from the interviews was that a form of collaborative learning took place with their peers as part of their normal socialising. Philda, in particular, is fond of socialising with her older neighbours, regularly looking in on them and also teaching them how to send text messages.

'Is lekker - ek kuier by hulle want hulle's oumense en ek geniet dit om saam met hulle te werk. Gaan drink bietjie koffietjies... Selfouns is baie beter as om niks te doen nie. Daar's baie dinge wat hulle kan leer - baie tekens soos padtekens in selfoun, nommers as jy miskien in nood verkeer.' (It's nice - I visit them because they are old people and I enjoy working with them. I go for some coffee...Cell phones are much better than doing nothing. There are many things they can learn - many signs like road signs in the cell phone, numbers if you have an emergency.)

In this regard, this study offers further confirmation of what Blommaert and Velghe (2012:9) note about the woman in their study and the type of scaffolded learning she experienced:

...textspeak proved to be an instrument for considerable progress and selfdevelopment. Whatever she possessed in the way of reading and writing skills was mobilized for it, and it was developed and made more specialized in it and through the collective efforts of a group of peers.

\section{Observations}

On the two occasions that the researcher was able to observe the group together while they enjoyed the hospitality of Philda's home, she was immediately struck by their enthusiasm as well as their fascination with learning to use different applications on their cell phones, like the calculator. The observations provided further evidence of the importance of the social dimension of learning (Hayes \& Hopkins, 1996) for these women. There was much laughter, pointing, teasing and boasting on these occasions. The women sat in pairs with their heads close together, bent over their phones while showing off their skills. Comments made during these sessions would typically include: 'Kyk hoe't ek nou geskrywe.' (Look at how I have just written.); 'Ek het mooier as jy geskrywe.' (I wrote nicer than you.); 'Nee jy skrywe verkeert!' (No, you are writing incorrectly!). 
The researcher also observed Philda in her role as literacy mediator helping some women to find letters and numbers on the keypads. Another interesting development that was observed on the second occasion was that one woman took out a pencil and a piece of paper and started to copy some letters from the keypad onto the paper - thereby possibly orienting herself to the more conventional semiotic forms of written literacy.

\section{The Content and Linguistic Analysis of the messages}

The discursive categories that emerged here showed that the largest number of messages dealt with maternal or family management discourses. This highlights the practical value of texting in the domain of greatest importance to these women. This category was followed by social messages and a smaller category containing messages with religious content.

Key: $\mathrm{SM}=$ messages sent by the women in the study; $\mathrm{RM}=$ messages received by them, and used with the permission of those senders. Translations as well as code switching into English are provided in italics.

1. Maternal/Family Management discourses

Examples:

- $\quad$ SM01: Ek.sit.di.taksie.ek+is.nou.daar (Sitting in the taxi. Almost there.)

- $\quad$ SM02: Bel vi anti T sy moet vi Brandon gan haal by kresh (Call aunty T. She must collect Brandon from the creche).

- $\quad$ SM03: Hallo N. stu vanmadag geld by SR as ek gepay het (Hallo N, sending money via Shoprite this afternoon once I've been paid).

- $\quad$ SM04: Ekke drink goou kovie bei mei ma mak dei ventirs toee vermeil (I am quickly having some coffee at my mother's house. Close the windows for me).

- $\quad$ RM01: Baaie gelik met jou virjardaag die kindirs moed die w a s g o e t e f ou d et op (Many happy returns on your birthday the children must fold up the washing).

- SM05: Gaant hal vermei teesaakkies bei die winkil (Get me some teabags from the shop).

These texting discourses can be said to be part of the family management strategies of these women, and reveal a variety of texting features and strategies. SMO1 uses the full-stop instead of the space icon to separate the words of her message, as this allows her to write the message faster in order to reassure her children that she is nearly home. All three senders also blend their Afrikaans messages with some English, as in their normal speech. Apart from the particular punctuation employed by SM01, the use of basic clippings is present in the messages sent by SM02 and SM03, e.g. 'vi' (vir - for); 'gan' (gaan - go) and 'stu' (stuur send). The other features are phonetic spelling of English words using Afrikaans letters (e.g. 'kresh' for 'creche'; 'taksie' for 'taxi' and 'anti' for 'aunty'); contractions blending English and Afrikaans (e.g. 'gepay' for 'been paid' in which 'ge' is the prefix used to form the past tense in Afrikaans). In contrast, the messages of SM04, RM01 and SM05 are written with no contractions but rely on phonetic spelling - i.e. these women write the messages exactly as they would speak them, and they do not appear to have mastered the various shortening strategies. There is also an absence of punctuation in these three messages, and RM01 also puts spaces between the individual letters of the word 'wasgoete' (washing) which may indicate that she was thinking carefully through the spelling of this word. These women may 
therefore have learned to use the keyboards of their cell phones to some extent but are still novices at using some of the other features of texting.

\section{Social messages}

Examples:

- $\quad$ SM06: Moeg van al die sport! 7de laan se repeat kommie meer oppie. WMJ? (I'm tired of all the sport! 7de Laan's repeat doesn't come on anymore. What are you doing.)

- $\quad$ SM07: Ek kry swaar my rent kom elke maand R90 Ek bid v (I'm struggling. My rent comes to R90 each month. I'm praying for).

- $\quad$ RM02: Btaal elke maand j rekening, gan rent office toe maak arrangement vetel wat $\mathrm{j}$ omstandighede is. Kyk hoeveel $\mathrm{j}$ ka btaal (Pay your account each month, go to the rent office, make arrangements, tell them what your circumstances are. See how much you can pay).

- $\quad$ RM03: Ja my dogter verjaarvan dag geluk met jou 40ste virjaarsdag dankie mooi dag en jaar jou ma M. (Yes my daughter is having a birthday today. Happy returns on your $40^{\text {th }}$ birthday. Thank you nice day and year your mother $\mathrm{M}$ ).

- $\quad$ RM04: Jy moeet ghou gesont rak ek keg an trouhe toe (You must get well soon. I am going to the wedding).

While the first (SM06) and last two messages (RM03 and RM04) are examples of basic socialising, the second and third messages (SM07 and RM02) are examples of seeking and receiving advice and support. In the first message, the sender uses the initialisms 'WMJ' for the stock expression 'Wat maak jy?' (What are you doing?). The use of such initialisms may indicate the presence of what is often referred to in the South African context as 'MXIT speech' - a reference to a popular local mobile instant messaging service that claims 10 million registered users - many under the age of 18 - who send over 250 million messages daily (Weimers, 2008). MXIT is also 'the cheapest way of communicating over the phone' in South Africa (Blommaert \& Velghe, 2012: 7). Writing in such initialisms may have been learned from a younger member of the family. In SM07, the woman needing advice dictated her message to a friend as she has some ability in reading, but is not able to write her own messages. Instead she relies on a literacy mediator, which makes her a type of apprentice. Literacy apprenticeship is central to Lave and Wenger's (1991) notion of situated learning, through which people participate with others to attain productive societal practices that benefit both themselves and their community. RM02 was clearly written by someone with a reasonable level of literacy as well as a fairly sophisticated command of clippings - 'btaal' instead of 'betaal' (pay); 'j' for 'jy' (you); 'gan' for 'gaan' (go), etc. In contrast, RM03 and RM04 avoid any shortenings and RM04 relies on phonetic spelling.

\section{Messages with religious content}

Examples:

- $\quad$ RM05: Bid vi jou. God will provide (Praying for you. God will provide).

- $\quad$ SM08: Ek geen haat $\mathrm{v}$ my seun se verdate kuller ni ek vergewe hom as ek d tronk of waar ookal die verdate is kan gaan en hom kan neem na plek waar hy god om vergifnis kan vra (I don't feel hatred for my son's alleged killer. I forgive him. If I can go to the 
prison or wherever he is, I can take him to a place where he can ask for God's forgiveness).

- SM09: Dankie tog daar is darem n gemeentes wat nog dink aan gebed xir die oorlog en moored wat nou so gebeer (Thank heaven there are still congregations who are thinking about praying for the wars and murders happening now).

The women in this study could all be said to be members of the Christian faith, and many messages had such religious content. In the above example, RM05 sends a message of support to SM08, whose son was murdered. She includes a stock English phrase 'God will provide' after starting her message in Afrikaans. SM08 responds in simple, unpunctuated lines marked by clippings ('vi' for 'vir'/for; 'd' for 'die/the and 'ni' for 'nie'/not) and one misspelt English word - kuller (for 'killer'). She also misspells the word 'verdate' (verdagte - alleged), although this might also be an attempt to reduce the number of characters used in this rather long message. SM09, in contrast, uses no clippings and contains three interesting errors - 'xir' instead of 'vir' (for) - which could simply indicate a slip of the finger; 'moored' instead of 'moorde' (murders) where the last two letters were probably unintentionally reversed; and the phonetic spelling of 'gebeer' instead of 'gebeur' (happening).

In terms of overall language use, it can be seen that these women predominantly use Afrikaans, with the occasional inclusion of English words and phrases like 'God will provide'. This provides confirmation of their close identification with the vernacular variety of Afrikaans that they use every day, which McCormick (2000), Malan (1996) and others regard as a mixed code which incorporates many English loanwords. It can also be noted that, while some make use of shortenings, others prefer to write in full sentences. In addition, they adjust their language use according to the persons with whom they are communicating.

\section{Evidence of Literacy Acquisition and Enhancement}

With some assistance from their literacy mediators, the research participants reported their perspectives on their literacy development in two ways - by sending mobile messages to the researcher's cell phone, or during discussions during the two meetings at Philda's house.

The first area of development and improvement reported on by the participants was that of text literacy. They reported either learning to read and write via texting for the first time, or improving their existing text literacy via texting. These two messages were sent to the researcher's cell phone:

- $\quad$ My naam is Malie ek kan nie skrywe nie Philda leer my om te skrywe op haar selfoon nee wat ons leer elke dag (My name is $R$. I can't write. P is teaching me to write on her cell phone. Yes, we learn every day).

- $\quad$ Ek is Willemina ek is 5o jaar ek was nooi op skool nie en ek het my leer skryf ( $I$ am $W$. I am 50 years old. I never went to school and I taught myself to write).

The constant daily interaction with the mobile telephones and assistance from those with some schooled literacy appeared to be bearing fruit with this group. In addition, tapping a keyboard is clearly physically less demanding than controlling a pen or pencil when writing, and there is the instant gratification of seeing complete letters or words emerging which are fully legible, unlike first attempts at handwriting. 
Secondly, some participants reported either developing or improving their numerical literacy. They had either been taught to use the calculator on their mobile telephones, or had received messages containing numbers which were interpreted for them by family members or friends. This can be seen in the following message sent to the researcher by Linda:

Ek is 80 jaar ek leer tel op selfoon en ek leer want ek doen self my syfers ek kan dankie sê vir my selfoon (I am 80 years old. I am learning to count on my cell phone, and I am learning because I am doing my own sums. I can say thanks to my cell phone).

The very act of interacting with a mobile telephone would naturally enhance people's visual literacy, and this was also an area reported on by the participants. They had become familiar with signs like emoticons, and in addition playing simple games available on their phones had also improved this particular type of literacy, which is essential in learning to navigate an urban environment filled with signage. When Willemina was interviewed, she reported on how Philda had helped her to use the mobile telephone which enabled her to learn to write as well as to play games on the phone:

'Sy wys my eers waar die spelwoorde is op die foun...so leer ek skryf, ook speletjies soos slangetjies...die selfoun is amper soos 'n skool'. (She first shows me where the spelling words are on the phone...that's how I learn to write, also games like snakies...the cell phone is almost like a school).

Lolla sent the following message, which provides proof of the type of intergenerational skills transfer referred to by Blommaert in his project proposal (2010):

'Ek is ouma Lolla ek nie skool gehet nie my keinkenders het my ga leer speletjies te speel my cellfone is my reder.' (I am granny L. I never went to school. My grandchildren taught me to play games on my cell phone. It's my salvation).

For three of the women, learning to play games to pass the time while looking after the grandchildren during the day was the actual starting point to them familiarising themselves with all the possibilities offered by the mobile telephone.

The final type of literacy which the data suggests is being acquired by these participants is the development of personal literacy. It is argued here that, in learning new forms of selfexpression from the messages of others, these women are able to articulate their feelings in new ways and to express their voice and emotions more clearly. In addition, their mobile phones provide a sense of security which enhances their personal agency, as can be seen in the following two interview extracts:

- Adri: 'Ek is nou 72 jaar oud. Ek leer nog altyd om te spel op my selfoon. Wat ek kan sê dat selfone is die beste vir kinders. As my kinders siek raak kan hulle my bel van die skool af. En nog ' $n$ ding jy kan in kontak bly met ver families. Ek bly in kontak met my beste vriendin P-. En die selfone hou die kinders van die draks af.' (I am 56 years old now. I am still learning to spell on my cell phone. What I can say is that the cell phones are the best for children. If my children fall ill, they can phone me from the school. And another thing, you can stay in contact with family living far away. I stay in contact with my best friend. And the cell phones keep the children away from drugs). 
- Malie: 'Die selfone is goet, ek kan net die panic kopie druk as ek in die moeilikheid is. Ek leer nog skrywe maar ek ken nie my nommer nie.' (The cell phones are good. I can just press the panic button if I am in trouble. I am still learning to write but I don't know my cell phone number).

Thus it is clear that texting offers the possibilities of literacy development and enhancement for these women, making their mobile phones extremely valuable resources. The women reported on here are unlikely ever to receive formal education, yet must have access to the world of text for them to negotiate the structures necessary for their survival in the city, and texting is clearly playing this role for them.

\section{CONCLUSIONS}

In conclusion, the question that must be answered is: why is this form of literacy acquisition effective for this particular group of women? It has already been noted that it draws on the social dimension of learning, which, according to Hayes and Hopkins (1996), is central to how adult women acquire literacy. As can be seen from the findings, these women are participating in collaborative learning through the sharing of common experiences about faith, home and family and negotiating living in an urban space to which most of them have migrated. In addition, learning takes place based on real-life communication situations and actual needs, therefore this type of learning is likely to be accompanied by strong motivation and enthusiasm, as was demonstrated by these women.

The data also reveals the effective sharing of literacy resources (including intergenerational transfer from children and grandchildren) which helps to empower these formerly silenced members of the community. This is the type of collective sharing and activation which Dyers and Slemming (2014 in press) contend is at the core of portable multiliteracies, which provides more opportunities for effective knowledge distribution and participatory citizenship. Deumert and Lexander (2013: 535) note that 'being a good texter means to draw on available resources and models and to employ them in locally meaningful ways'. What might therefore not be valued in other contexts is certainly valued and understood by this group and their family members, giving them greater self-confidence and the ability to make themselves understood to others. Like the woman in the study by Blommaert and Velghe (2012:15), these women's use of texting 'is not primarily a use of a "language", it is a deployment of voice - of a sign system that opens channels of peer-group communication and conviviality'.

Last, but certainly not least, participant after participant stressed the enjoyable 'game-like' and repetitive quality of this form of learning, which means that the learning was almost completely stress-free and offered the instant gratification of seeing signs after simply tapping the phone's keyboard.

In contrast to the often negative perceptions of the effects of mobile messaging on the spelling and grammar of users, it is argued in this paper that we are dealing here with an underexploited literacy resource which could be incorporated more fully in formal learning, given its popularity, accessibility and effectiveness as a learning tool. All forms of portable multiliteracies have the potential of improving the literacy levels of ordinary people with 
limited or incomplete education, thereby increasing their potential for full participatory citizenship.

Acknowledgements: The researcher wishes to acknowledge the important role played by the key informant, Philda Franse of Netreg, Cape Town, in giving the researcher access to her group of friends. The larger study on 'Township Women's Discourses and Literacies' was funded by the National Research Foundation of South Africa.

\section{REFERENCES}

BAYNHAM, M. 2004 Literacy practices: investigating literacy in social context. London: Longman.

BIESWANGER, M. 2007. 2 abbrevi8 or not 2 abbrevi8: a contrastive analysis of different shortening strategies in English and German texts. In Hallett, T, S Floyd, S Oshima \& A Shields (Eds), SALSA (Symposium about Language and Society) XIV Proceedings, Austin, Texas 2006.

BLOMMAERT, J. 2010. A sociolinguistics of globalization. Cambridge: Cambridge University Press.

BLOMMAERT, J \& F VELGHE. 2012. Learning a supervernacular: textspeak in a South African township. Working Papers in Urban Linguistics (WPULL Kings College) Paper 88 [Online]. Available:

www.kcl.ac.uk/sspp/departments/education/research/ldc/88.pdf. [2014, 1 April].

CRYSTAL, D. 2001. Language and the Internet. Cambridge: Cambridge University Press.

DEUMERT, A \& K LEXANDER. 2013. Texting Africa: writing as performance. Journal of Sociolinguistics, 17(4):522-546.

DYERS, C, M WILLIAMS \& T BARTHUS. 2012. Emotion, voice and agency: exploring the written discourses of some township women in South Africa. South African Journal of Linguistics and Applied Language Studies, 30(1):1-11.

DYERS, C \& F SLEMMING. 2014 (in press). Neither helpless nor hopeless: portable multiliteracies, discourses and agency in a 'township of migrants' in Cape Town. In Juffermans, K, YM Asfaha \& AK Abdelhay (Eds), African literacies: scripts, ideologies, education, Chapter 12. Newcastle-upon-Tyne: Cambridge Scholars.

GEE, J. 1990. Social linguistics and literacies: ideologies in discourse. London: Falmer Press.

GIROUX, H. 1988. Schooling and the Struggle for Public Life: Critical Pedagogy in the Modern Age. Minneapolis: University of Minnesota Press.

GREGORY, E, S LONG \& D VOLK (Eds). 2004. Many pathways to literacy: young children learning with siblings, grandparents, peers, communities. London: Routledge.

HAYES, E \& J HOPKINS. 1996. 'Gender and Literacy Learning: Implications for Research in Adult Literacy Education'. Paper presented at the American Educational Research Association Annual Conference, NYC, New York, April 1996.

HERNANDEZ-ZAMORA, G. 2010. Decolonizing Literacy. Mexican Lives in the Era of Global Capitalism. Bristol: Multilingual Matters. 
IEDEMA, R. 2003. Multimodality, resemiotization: Extending the analysis of discourse as multi-semiotic practice. Visual Communication, 2(1):29-57.

KENNER, C; RUBY, M; JESSEL, J; GREGORY, E \& ARJU, T. 2007. Intergenerational learning between children and grandparents in east London. Journal of Early Childhood Research 5(3):219-243.

KURNIAWAN, S, M MAHMUD \& Y NUGROHO. 2006. 'A study of the use of mobile phones by older persons'. CHI 2006, April 22-27, 2006, Montreal, Quebec, Canada.

LAVE, J \& E WENGER (Eds). 1991.Situated learning: legitimate peripheral participation. Cambridge, MA: Cambridge University Press.

LEXANDER, K. 2011. Texting and African language literacy. New Media and Society, 1-17 [Online]. Available:

http://nms.sage.pub.com/content/early/2011/03/12/146144481039 [2011, 5 May].

MACHENG, C. 2011. Local ways of knowing: schooling, language and literacy in a marginal, culturally distinctive community in Botswana. Unpublished M Ed minor dissertation. Cape Town: UCT.

MALAN, K. 1996. Cape Flats English. In De Klerk, V (Ed) Varieties of English around the world (General Series), Vol. 15: Focus on South Africa, pp. 125-148. Amsterdam: John Benjamins.

MASNY, D. 2005. Multiple literacies: an alternative or beyond Freire. In Anderson, J, M Kendrick, T Rogers \& S Smythe (Eds), Portraits of literacy across families, communities and schools: intersections and tensions. London: Lawrence Erlbaum.

McCORMICK, K. 2000. Language in Cape Town's District Six. Oxford: Oxford University Press.

MELENHORST, A, WA ROGERS \& EC CAYLOR. 2001. 'The use of communication technologies by older adults: exploring the benefits from the user's perspective.' In Proc. HFES 46th Annual Meeting, HFES Press (2001), 221-225.

MILLS, K. 2011. The multiliteracies classroom. Bristol: Multilingual Matters.

PORTER, G. 2011. Young people, mobile phones and virtual mobility - a three-country study. Seminar presented in the Department of Anthropology and Sociology, University Western Cape, 20 April 2011.

ROCKHILL, K. 1993. Gender, language and the politics of literacy. In Street, B (Ed), Crosscultural approaches to literacy. Cambridge, UK: Cambridge University Press.

SCHINKEL, W. 2008. The moralisation of citizenship in Dutch integration discourse. Amsterdam Law Forum, 1(1):15-26. VU University Amsterdam.

SLEMMING, F. 2011. An exploration of the link between selected women's discourses and literacy resources in the working class township settlement of Wesbank, South Africa. Unpublished MA thesis, Bellville: University of the Western Cape.

STEMLER, S. 2001. An overview of context analysis. Practical Assessments Research and Evaluation, 7(17) [Online]. Available: http:// PARE online, net/ getvn.asp?v=7\&n $=17$ [2013, 5 April].

STREET, B (Ed). 1993. Cross-cultural approaches to literacy. Cambridge, UK: Cambridge University Press. 
STREET, B. 1995. Social literacies: critical approaches to literacy in development, ethnography, and education. London: Longman.

STREET, B. 2003. What's "new" in New Literacy Studies? Critical approaches to literacy in theory and practice. Current Issues in Comparative Education, 5.2:77-91.

STROUD, C. 2009. Response to Blommaert: language, asylum and the national order. Current Anthropology, 50(4):434-435.

SUTTON, M. 2008. Knowledge citizenship for active informed citizenship. South African Journal of Information Management, 10(4):1-5.

THURLOW, C. 2003. Generation txt? The sociolinguistics of young people's text-messaging. Discourse Analysis Online, 1(1) [Online]. Available:

http://www.shu.ac.uk/daol/articles/v1/n1/a3/thurlow2002003-paper.html [2008, 15 December].

THURLOW, C \& M POFF. 2009. The language of text messaging. In Herring, SC, D Stein \& $\mathrm{T}$ Virtanen (Eds). Handbook of the pragmatics of CMC. Berlin and New York: Mouton de Gruyter.

TORKELSON, E. 2009. Netreg housing project: remaking city and vernacular economy according to communal needs and desires. Cape Town: Development Action Group.

UNSWORTH, L. 2008. Negotiating new literacies in English teaching. In Unsworth, L (Ed), New literacies and the English curriculum, pp. 3-19. London: Continuum.

WEIMERS, M. 2008. 2 Mix or nt 2 MIX? (Dats d kwestion): The effect of instant messaging on Afrikaans-speaking adolescents in South Africa. Undergraduate research report, Division of Speech, Language and Hearing therapy, Stellenbosch University.

WILLIAMS, M. 2012. Negotiating the linguistic landscape: women, literacy and citizenship in one South African Township. Unpublished MA thesis. Bellville: University Western Cape.

\section{BIOGRAPHIC NOTE}

Charlyn Dyers is an associate professor in Linguistics at the University of the Western Cape. Her research interests include language attitudes and language ideologies in Africa, urban multilingualism and intercultural communication. A major focus of her research is the discourses and literacy practices of township women in Cape Town. E-mail: cdyers@uwc.ac.za 